\title{
Water Resources of Lac Vieux Desert Indian Community and Vicinity, Western Upper Peninsula, Michigan
}

U.S. Department of the Interior

U.S. Geological Survey

Water-Resources Investigations Report 98-4051

Prepared in cooperation with the

Lac Vieux Desert Band of Lake Superior

Chippewa Indians

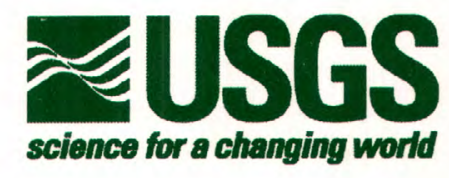





\section{Water Resources of Lac Vieux Desert Indian Community and Vicinity, Western Upper Peninsula, Michigan}

By Gary J. Barton and Norman G. Grannemann

U.S. Department of the Interior

U.S. Geological Survey

Water-Resources Investigations Report 98-4051

Prepared in cooperation with the

Lac Vieux Desert Band of Lake Superior

Chippewa Indians 


\title{
U.S. DEPARTMENT OF THE INTERIOR \\ BRUCE BABBITT, Secretary
}

\author{
U.S. GEOLOGICAL SURVEY \\ Charles G. Groat, Director
}

For additional information write to:

District Chief U.S. Geological Survey, WRD 6520 Mercantile Way, Suite 5 Lansing, MI 48911-5991
Copies of this report can be purchased from:

U.S. Geological Survey Branch of Information Services

Box 25286

Denver, CO 80225-0286 


\section{Contents}

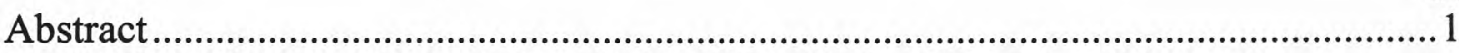

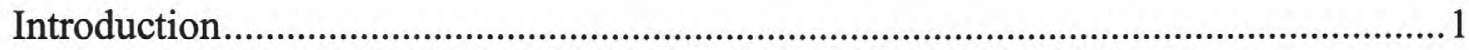

Description of the Lac Vieux Desert Study Area.................................................. 1

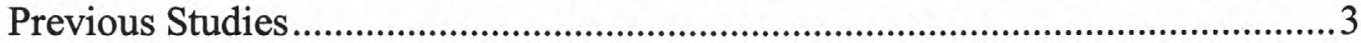

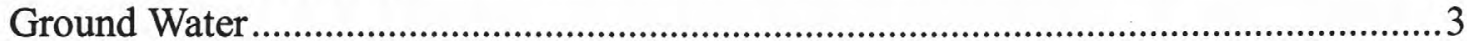

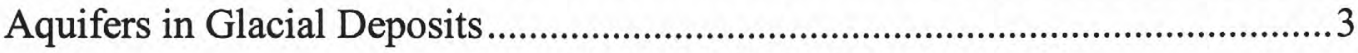

Tritium Analyses for Determining Age of Ground Water ................................... 5

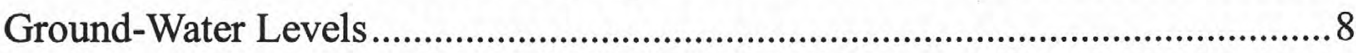

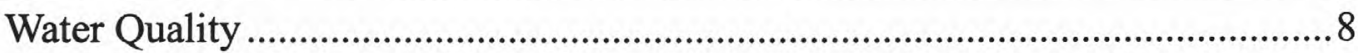

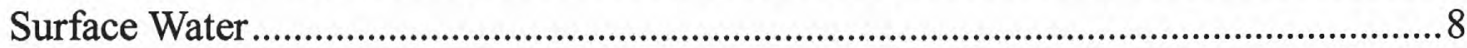

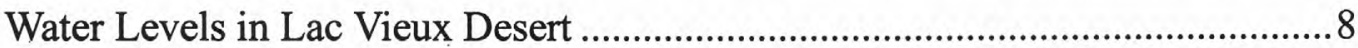

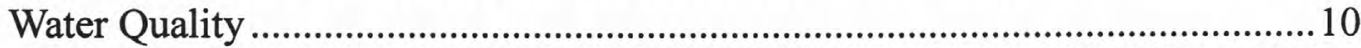

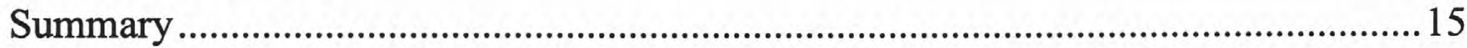

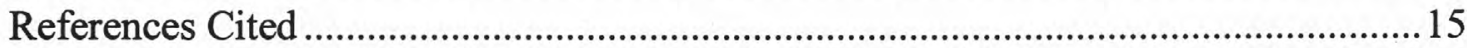

Figures

1. Map showing the Lac Vieux Desert study area and location of wells used for

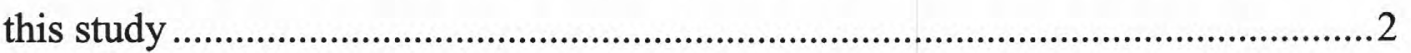

2. Map showing sampling locations for water quality on Lac Vieux Desert ...............4

3. Chart showing preliminary hydrogeologic section at Lac Vieux Desert ...................7

4. Graph showing water levels at Lac Vieux Desert, 1913-95................................... 11

\section{Tables}

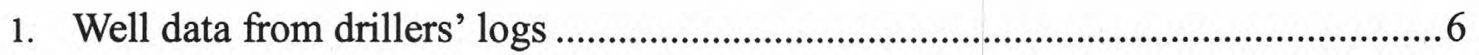

2. Physical and chemical characteristics of water from wells near Lac Vieux

Desert and water quality standards for human consumption ....................................

3. Physical and chemical characteristics of water from three sites on Lac Vieux

Desert, March 1996.

4. Physical and chemical characteristics of water from ten sites on Lac Vieux

Desert, October 1996

5. Physical characteristics of water in Lac Vieux Desert at five sites profiled

October 1996. 


\section{CONVERSION FACTORS AND VERTICAL DATUM}

\section{CONVERSION FACTORS}

\begin{tabular}{lll}
\hline Multiply & By & To obtain \\
\hline inch & 25.4 & millimeter \\
foot $(\mathrm{ft})$ & 0.3048 & meter \\
mile $(\mathrm{mi})$ & 1.609 & kilometer \\
foot per day $(\mathrm{ft} / \mathrm{d})$ & 0.3048 & meter per day \\
foot per second $(\mathrm{ft} / \mathrm{s})$ & 30.48 & centimeter per second \\
gallon per minute $(\mathrm{gpm})$ & 0.06309 & liter per second \\
cubic foot $\left(\mathrm{ft}^{3}\right)$ & 0.02832 & cubic meter \\
million gallons per day $(\mathrm{Mgal} / \mathrm{d})$ & 0.003785 & cubic meters per day \\
square foot $\left(\mathrm{ft}^{2}\right)$ & 0.09290 & square meter \\
square mile $\left(\mathrm{mi}^{2}\right)$ & 2.590 & square kilometer \\
\hline
\end{tabular}

VERTICAL DATUM: In this report, "sea level" refers to the National Geodetic Vertical Datum of 1929a geodetic datum derived from a general adjustment of the first-order level nets of both the United States and Canada, formerly called Sea Level Datum of 1929. 


\section{Water Resources of Lac Vieux Desert Indian Community and Vicinity, Western Upper Peninsula, Michigan}

\author{
By Gary J. Barton and \\ Norman G. Grannemann
}

\section{ABSTRACT}

Lac Vieux Desert, a 6.6 square-mile lake on the Michigan-Wisconsin border, is the headwaters of the Wisconsin River. The Lac Vieux Desert Band of Lake Superior Chippewa Indians have a number of homes and tribal property on the Lake's north shore. Most drinking water is obtained from wells drilled in unconsolidated glacial deposits. A gravel layer at or near the bedrock surface is the most productive aquifer on tribal property.

Water quality of Lac Vieux Desert is a concern for tribal members. To assess general water-quality conditions, water samples were collected at three sites on the lake in March 1996 and at 10 sites in October 1996. Profiles of $\mathrm{pH}$, dissolved oxygen, specific conductance, and temperature indicate that the lake is well mixed in the fall but not when the lake is ice covered in winter.

Between 1913 and 1995, the minimum and maximum daily recorded lake levels were $1,679.28$ feet (in 1925) and 1,682.16 feet (in 1951) above sea level. Since the early 1950 's, the annual minimum lake-level has been lower and less variable than before the 1950's. Although the level of Lac Vieux Desert is regulated, historical levels show year-to-year fluctuations that reflect transient changes in precipitation amounts.

\section{INTRODUCTION}

The Lac Vieux Desert Band of Lake Superior Chippewa Indians rely on wells completed in glacial deposits to provide a reliable source of potable water for domestic and community uses. Recently, a number of Indian Community homes have been built on a parcel of land on the northern shore of Lac Vieux Desert, which is the name adopted by this Band and also the name for a natural lake near their community. The homes have individual wells and septic systems.

The water level of Lac Vieux Desert was twice raised several feet by construction, modification, and operation of a dam on the lake's outlet. A wooden dam was first constructed about 1870 to regulate flow for transporting logs down the Wisconsin River. During 1937, the wooden dam was replaced with a concrete and steel structure and the lake level was raised to help control flow in the Wisconsin River for hydroelectric power production.

Elevated water levels may have affected the lake's ability to sustain growth of wild rice, which is important both culturally and as a food source for the Chippewa throughout the Great Lakes area. The Lac Vieux Desert Indian Community requested that the USGS evaluate surface- and ground-water resources on and near Lac Vieux Desert to address ground-water quantity and quality for water supply, and to characterize long-term lake-level fluctuations and lake water quality as factors that may be important for reintroduction of wild rice in the lake. This report provides information about water quantity and quality at Lac Vieux Desert that may help the community make decisions about water-resource issues.

\section{Description of the Lac Vieux Desert Study Area}

Lac Vieux Desert covers 6.6 square miles $\left(\mathrm{mi}^{2}\right)$, about half of which is in Gogebic County, Michigan and half in Vilas County, Wisconsin (fig. 1). The lake and small tributaries to the lake are the headwaters of the Wisconsin River. Water levels at the lake are about 1,680 feet (ft) above sea level; water depths average about $15 \mathrm{ft}$ and range from about $5 \mathrm{ft}$ in Rice Bay to about $30 \mathrm{ft}$ in the south-central part of the lake. A general comparison of the size and configuration of the lake before the first dam was constructed and the current size of the lake was made by comparing land plat survey maps drawn in 1852 and 1863 with current maps of the lake. However, the early survey plat maps were not drawn with sufficient 


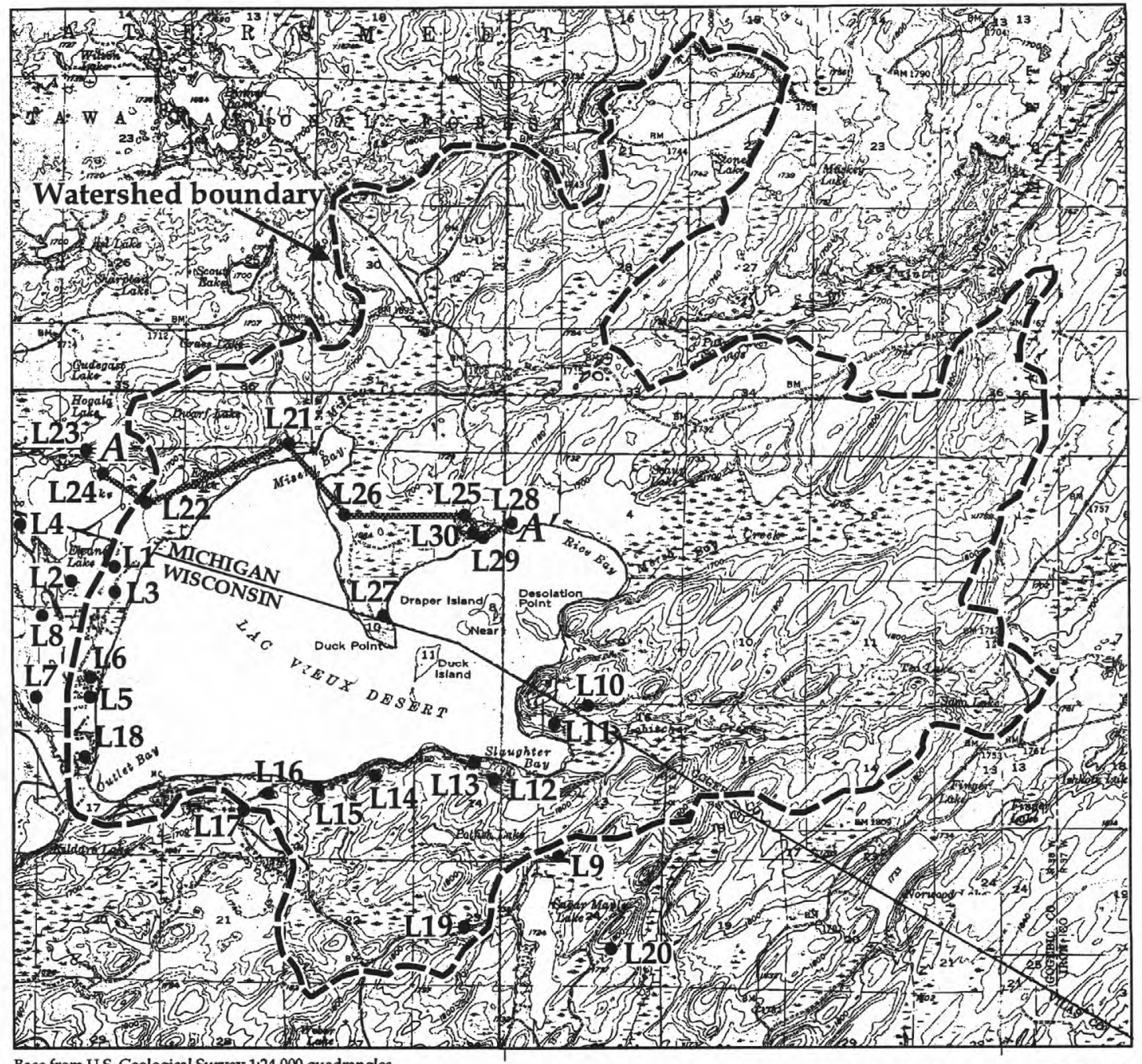

Base from U.S. Geological Survey 1:24,000 quadrangles.
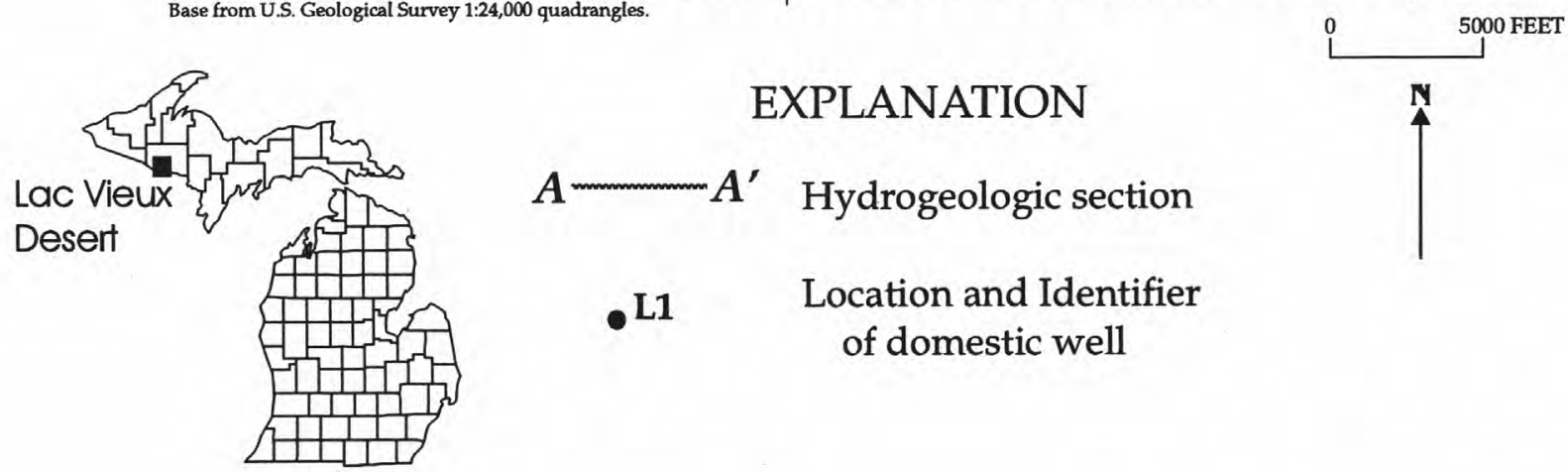

MICHIGAN

Figure 1. Lac Vieux Desert study area and location of wells used for this study. (See figure 3 for hydrogeologic section.) 
detail to make more than a general comparison. Water levels of Lac Vieux Desert are regulated between a minimum level of 1,679.37 and maximum level of $1,681.53 \mathrm{ft}$ above sea level (John Kaskey, oral commun., Lac Vieux Desert Dam Caretaker, 1996).

Lac Vieux Desert drains a $34.4 \mathrm{mi}^{2}$ watershed. Marsh Bay Creek, Misery Creek, and Lobischer Creek flow into the lake (fig. 1). Land-surface elevations in the watershed range from about 1,680 to $1,865 \mathrm{ft}$ above sea level. Inspection of U.S. Geological Survey 7.5 minute topographic quadrangle maps indicate that the watershed includes about $4 \mathrm{mi}^{2}$ of wetlands and five smaller lakes.

Land-surface features in the Lac Vieux Desert watershed range from flat lying plains and wetlands to rolling hills. These features are mostly the result of sediment deposition by continental glaciers that melted about 10,000 years ago, leaving debris as thick as $200 \mathrm{ft}$ (Attig, 1985, plate 1 and fig. 1).

Flat-lying or gently sloping plains and some submerged areas along the south-central, western, and northern parts of the lake are underlain by stratified sand and gravel deposits (braided-stream sediment in plains). Wetlands and some submerged areas are capped with organic-rich sediments in areas bordering Misery Bay, Rice Bay, and Slaughter Bay, the western lake shore, the Indian Community land trust, and extensive areas along Marsh Bay, Misery, and Lobischer Creeks. These organicrich sediments are generally underlain with sand and gravel and some clay.

The landscape is primarily rolling, in part due to drumlin landforms, which are rounded hills that were shaped by glacial ice about 10,000 years ago. The drumlins consist of poorly stratified silty and clay-rich glacial sediment and compact, gravelly sandy till that forms a discontinuous cover over stratified sand and gravel. The long axes of these hills are parallel to the direction of glacial ice movement. Drumlins are present primarily along the southern and eastern edges of the lake.

\section{Previous Studies}

Attig (1985) reported on the Pleistocene geology of Vilas County, Wisconsin. Morey and others (1982) studied the bedrock geology of the Lake Superior region. The U.S. Natural Resource Commission (Lawrence Kerrey and David Hvizdak, U.S. Natural Resource Commission, written commun., 1995) and the U.S. Forest Service (Sarah Mase, U.S. Forest Service, written commun., 1995) have mapped soil types at Lac Vieux Desert. Doonan and Hendrickson (1968) described the groundwater resources of Gogebic County, Michigan. Patterson (1989) reported on the water resources of Vilas County, Wisconsin and sampled three wells located less than one mile south and west of Lac Vieux Desert. The Wisconsin Valley Improvement Company (WVIC) monitored the water quality of Lac Vieux Desert at site 5 (fig. 2) during the spring, summer and fall of 1979-83 (Wisconsin Valley Improvement Company, 1990).

\section{GROUND WATER}

Ground-water supplies in the Lac Vieux Desert watershed are obtained from wells drilled in Pleistocene glacial deposits that are underlain by quartzose metasedimentary rock, granite, and amphibolite, all of Precambrian age (Morey and others, 1982). Because bedrock in this area generally yields small quantities of water, the top of bedrock is considered to be the base of the aquifer system.

\section{Aquifers in Glacial Deposits}

Construction records for wells in the Lac Vieux Desert watershed indicate that all wells are screened above the bedrock surface (table 1). A hydrogeologic section for the northern shore of Lac Vieux Desert, developed from information in seven drillers' logs, is shown in figure 3.

Aquifers in the Lac Vieux Desert watershed chiefly comprise stream-deposited sand and gravel from $5 \mathrm{ft}$ to tens of $\mathrm{ft}$ thick (fig. 3). Confining layers of till and debris-flow sediment range from about 10 to $100 \mathrm{ft}$ thick. Confining layers are commonly described in well 


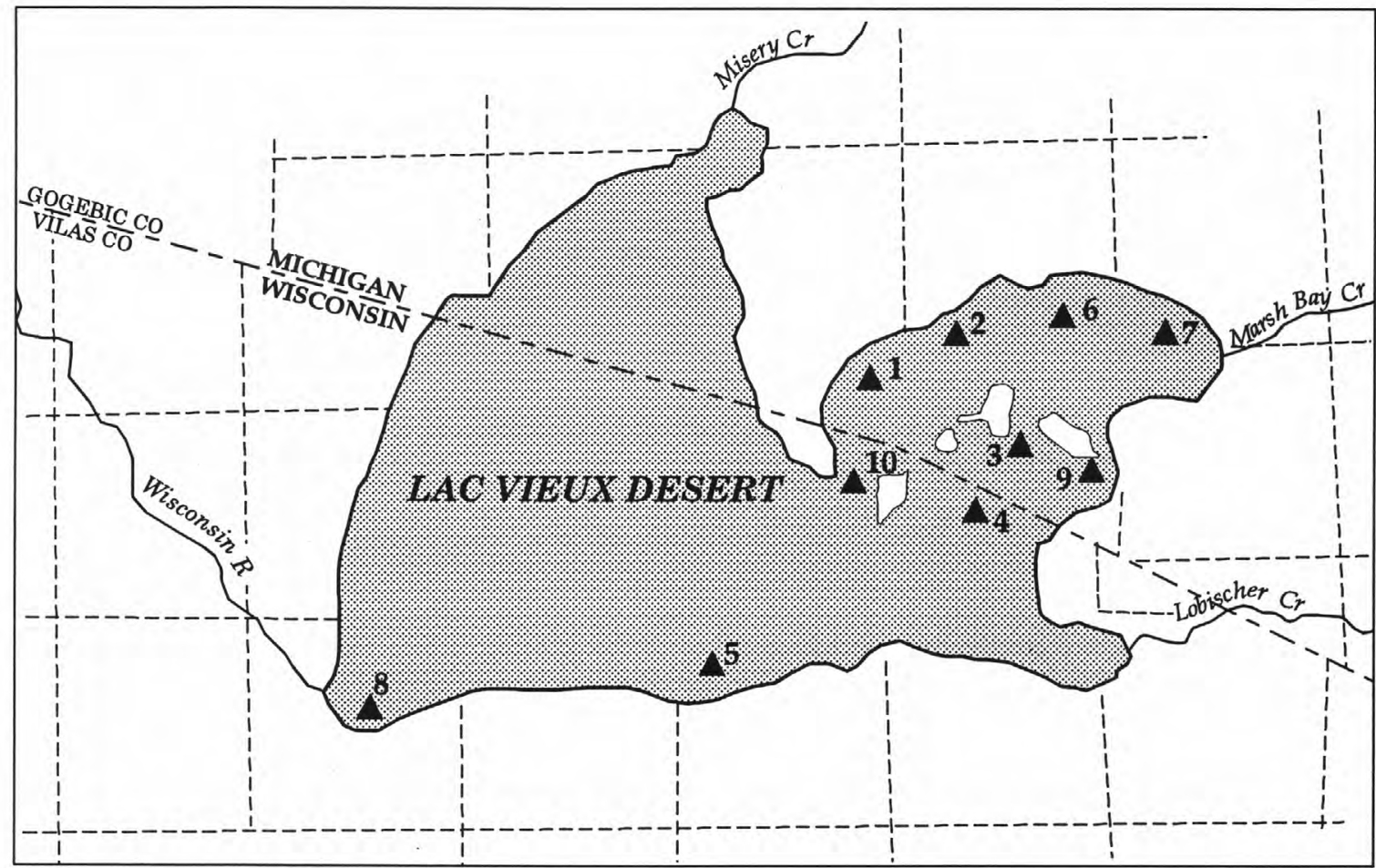

Base from Wisconsin Valley Improvement Company

0

5000 FEET

\section{EXPLANATION \\ $\Delta$ Sampling site location and identifier}

Figure 2. Sampling locations for water quality on Lac Vieux Desert. 
construction records as a 'hard pan clay' or 'hard clay' and sometimes include boulders and fine sand (fig. 3). Most wells in the area are screened in stream-deposited sand and gravel; however, a few wells may obtain small amounts of water from till and debris-flow sediments. Clay confining layers overlying sand and gravel aquifers were logged on 19 of the 29 well records listed in table 1 . Most of these wells penetrate a multiple-aquifer system consisting of an upper water-table aquifer and a lower confined aquifer(s). Moreover, in most of these wells it is the confined aquifer that yields the greatest amount of water. A few wells may penetrate only a confined aquifer. Drillers' logs for wells L4, L9, L10, L11, L13, L14, L16, L17, and L27 indicate that the deepest confined aquifer is a discontinuous gravel layer that can yield water at rates as great as 30 gallons per minute (gpm). The upper surface of this gravel aquifer ranges from about 96 to 188 $\mathrm{ft}$ below land surface with a minimum thickness of $3 \mathrm{ft}$. The maximum thickness reported in the well logs is $15 \mathrm{ft}$; the maximum thickness of the aquifer is unknown, however, because the aquifer was not fully penetrated by any of the wells. In some areas the gravel aquifer may be lying directly on the bedrock surface.

Drillers' logs indicate that sand lenses are present between 44 and 78, 21 and 42, and 68 and $84 \mathrm{ft}$ below land surface in wells L25, L28, and L29, respectively. The bottom of well L25 is comprised of till and flow-debris sediment which is mostly hard clay. This clay layer overlies and probably confines a stream-deposited sand and gravel aquifer. Well L27 (fig. 3), which is about one mile west of the Indian Community, is $120 \mathrm{ft}$ deep and penetrates a sand and gravel aquifer at 50 to $60 \mathrm{ft}$ and, again, at 106 to $120 \mathrm{ft}$ below land surface.

Hydraulic properties of the aquifers are needed to assist with delineating contributing areas for some wells near the Lake. Patterson $(1989$, table 3$)$ analyzed the geologic logs for two wells located near the southwestern shoreline, and used slug-test data to calculate a horizontal hydraulic conductivity of about $17 \mathrm{ft}$ per day $(\mathrm{ft} / \mathrm{d})$ for sand and gravel and $0.08 \mathrm{ft} / \mathrm{d}$ for sandy till. The geometric means of the hydrau- lic conductivities for slug-tests performed in 31 of 39 wells finished in sand and gravel in Vilas County was calculated to be $24 \mathrm{ft} / \mathrm{d}$ and for 10 wells finished in silty and clayey till or debris-flow material was calculated to be 0.23 $\mathrm{ft} / \mathrm{d}$ (Patterson, 1989, p. 16). There are no reported aquifer tests at the Lac Vieux Desert Indian Village Community besides the well acceptance test reported in well construction records.

\section{Tritium Analyses for Determining Age of Ground Water}

Tritium is a natural radioactive isotope of hydrogen that has a half-life of 12.3 years. The concentration of tritium in a water sample can be used to determine if the water entered the ground-water system prior to the beginning of nuclear testing in the atmosphere in 1953 and, thus, help determine how readily precipitation enters the ground-water system. The natural concentration of tritium in precipitation is about 5 tritium units (TU); however, atmospheric detonation of nuclear weapons added large quantities of tritium to precipitation during the 1950's and 1960's. Tritium concentrations in ground water recharged before 1953, when the first hydrogen bomb was detonated, generally are less than 2 TU. Tritium concentrations less than $2 \mathrm{TU}$ indicates that an aquifer is not recharged rapidly from precipitation at the land surface and is less vulnerable to contamination.

Water samples from three wells at the Lac Vieux Desert Indian Community were analyzed for tritium. The concentrations of tritium in water from wells L28, L29, and L30 were $19.7,20.2$, and $22.5 \mathrm{TU}$, respectively (table 2), which indicate that at least some of the water in the glacial aquifer at depths of about $80 \mathrm{ft}$ deep, was in contact with atmosphere within the last 40 years. These tritium concentrations support the well-log data, which indicate that the shallow aquifer is largely unconfined and thus recharged fairly rapidly because the till layer, which has confining characteristics, is discontinuous. Water samples from the deeper aquifer, which lies at depths greater than $106 \mathrm{ft}$ below land surface, were not tested, but that 
Table 1. Well data from drillers' logs

[ft, feet; bls, below land surface; gpm, gallons per minute; T \& R, Township and Range; --, no data]

\begin{tabular}{|c|c|c|c|c|c|c|c|}
\hline $\begin{array}{l}\text { Well } \\
\text { Number }\end{array}$ & $\begin{array}{l}\text { Depth } \\
\text { drilled } \\
\text { (ft bls) }\end{array}$ & $\begin{array}{l}\text { Screened } \\
\text { interval } \\
\text { (ft bls) }\end{array}$ & $\begin{array}{l}\text { Static } \\
\text { water level } \\
(\mathrm{ft} b l s)\end{array}$ & $\begin{array}{l}\text { Pumped } \\
\text { water level } \\
\text { (ft bls) }\end{array}$ & $\begin{array}{l}\text { Pumping } \\
\text { rate } \\
(\mathrm{gpm})\end{array}$ & $\begin{array}{l}\text { Well } \\
\text { diameter } \\
\text { (inches) }\end{array}$ & $\begin{array}{l}\text { Well } \\
\text { location } \\
(\mathrm{T} \& \mathrm{R})\end{array}$ \\
\hline $\mathrm{L} 1$ & 105 & open & 12 & 19 & 1.5 & 6 & $42 \mathrm{~N} 11 \mathrm{E} 5$ \\
\hline L2 & 43 & $40-43$ & 10 & 15 & 15 & 6 & $42 \mathrm{~N} 11 \mathrm{E} 5 \mathrm{CD}$ \\
\hline L3 & 43 & $40-43$ & 7 & 30 & 18 & 6 & 42N11E5DD \\
\hline $\mathrm{L} 4$ & 178 & open & 15 & 150 & 6 & 6 & $42 \mathrm{~N} 11 \mathrm{E} 6 \mathrm{AC}$ \\
\hline L5 & 48 & $20-48$ & flowing & 48 & 25 & 6 & $42 \mathrm{~N} 11 \mathrm{E} 8$ \\
\hline L6 & 44 & $41-44$ & 10 & 25 & 18 & 6 & $42 \mathrm{~N} 11 \mathrm{E} 8 \mathrm{DC}$ \\
\hline $\mathrm{L7}$ & 83 & $80-83$ & 20 & 40 & 35 & 6 & $42 \mathrm{~N} 11 \mathrm{E} 8 \mathrm{CB}$ \\
\hline L8 & 165 & $163-165$ & 18 & -- & -- & 6 & 42N11E8BB \\
\hline L9 & 155 & $151-155$ & 120 & 125 & 15 & 4 & $42 \mathrm{~N} 11 \mathrm{E} 13 \mathrm{CC}$ \\
\hline L10 & 191 & open & 112 & 123 & 17 & 6 & 42N11E13BD \\
\hline L11 & 145 & $140-145$ & 60 & 64 & 30 & 6 & $42 \mathrm{~N} 11 \mathrm{E} 13 \mathrm{BB}$ \\
\hline $\mathrm{L} 12$ & 98 & $94-98$ & 30 & 80 & 7 & 6 & $42 \mathrm{~N} 11 \mathrm{E} 14$ \\
\hline L13 & 192 & open & 14 & 32 & 30 & 6 & $42 \mathrm{~N} 11 \mathrm{E} 14$ \\
\hline L14 & 103 & $99-103$ & -- & 42 & 18 & 4 & $42 \mathrm{~N} 11 \mathrm{E} 15$ \\
\hline L15 & 116 & $106-116$ & 87 & 103 & 5 & 6 & $42 \mathrm{~N} 11 \mathrm{E} 15$ \\
\hline L16 & 169 & open & 70 & 80 & 25 & 6 & 42N11E16BDD \\
\hline $\mathrm{L} 17$ & 125 & open & 60 & 65 & 10 & 6 & $42 \mathrm{~N} 11 \mathrm{E} 16 \mathrm{AC}$ \\
\hline L18 & 123 & open & 15 & 20 & 15 & 4 & $42 \mathrm{~N} 11 \mathrm{E} 17 \mathrm{BB}$ \\
\hline L19 & 87 & $83-87$ & 55 & 60 & 10 & 6 & $42 \mathrm{~N} 11 \mathrm{E} 23$ \\
\hline $\mathrm{L} 20$ & 100 & $96-100$ & 40 & 55 & 15 & 4 & $42 \mathrm{~N} 11 \mathrm{E} 24$ \\
\hline L21 & 105 & $101-105$ & 5 & 30 & 15 & 4 & $43 \mathrm{~N} 39 \mathrm{~W} 1 \mathrm{CB}$ \\
\hline L22 & 128 & $124-128$ & 22 & 28 & 15 & 4 & $43 N 39 W 2$ \\
\hline L23 & 98 & $95-98$ & 15 & 35 & 20 & 6 & $43 \mathrm{~N} 39 \mathrm{~W} 2 \mathrm{BBD}$ \\
\hline L24 & 72 & $68-72$ & 15 & 32 & 10 & 4 & $43 N 39 W 2 B B$ \\
\hline L25 & 80 & $67-77$ & 26 & 65 & 12 & 6 & $43 \mathrm{~N} 38 \mathrm{~W} 5 \mathrm{CA}$ \\
\hline L26 & 49 & $44-49$ & 18 & 20 & 10 & 6 & 43N38W6BC \\
\hline L27 & 120 & open & 35 & 40 & 10 & 6 & $43 \mathrm{~N} 38 \mathrm{~W} 7$ \\
\hline L28 & 84 & $81-84$ & -- & -- & -- & 6 & 43N38W5DB \\
\hline L29 & 42 & $39-42$ & -- & -- & -- & 6 & $43 N 38 W 5 C B$ \\
\hline L30 & - & -- & -- & -- & -- & 6 & $43 N 38 W 5 C D$ \\
\hline
\end{tabular}



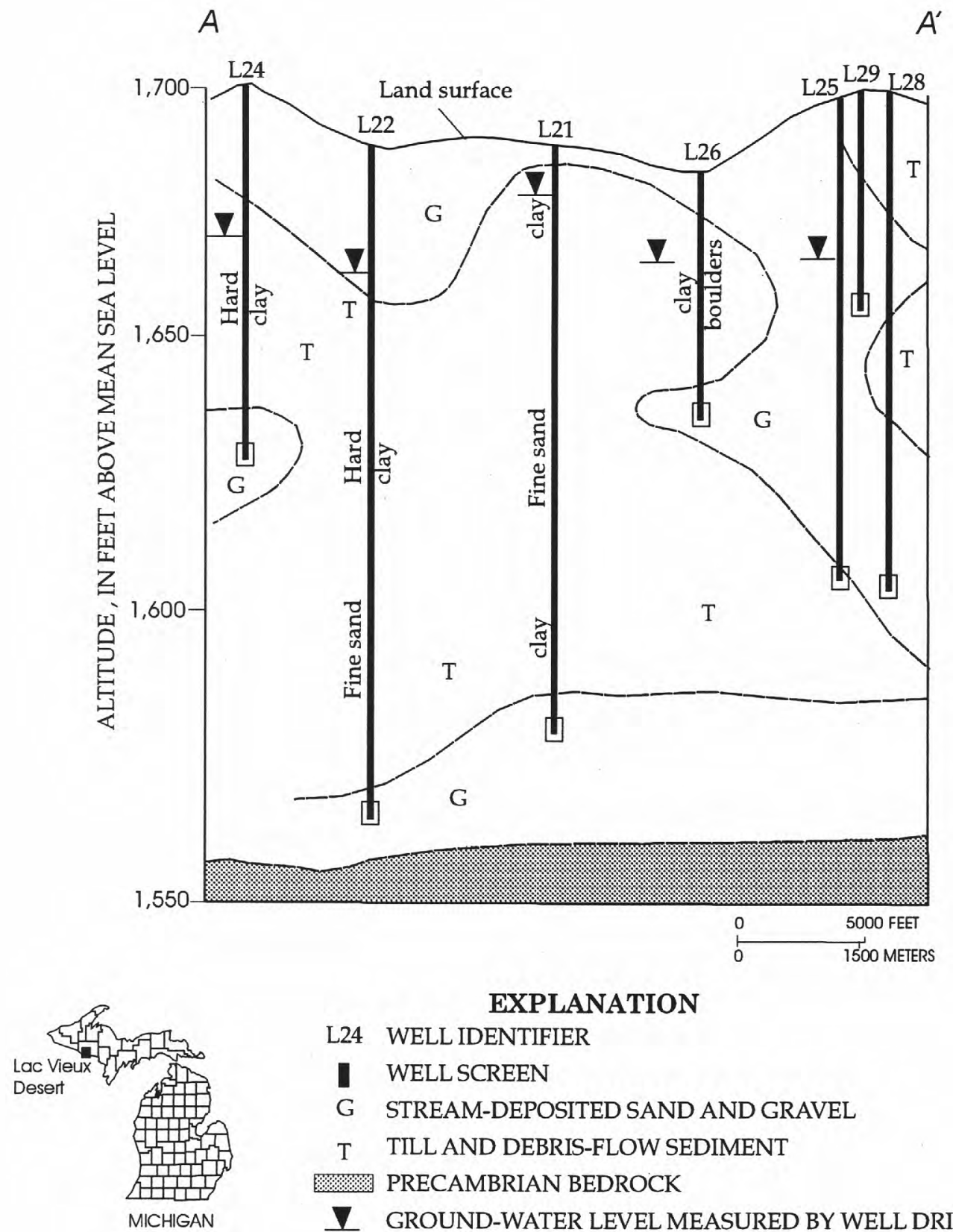

EXPLANATION

PR.:. PRECAMBRIAN BEDROCK

\ GROUND-WATER LEVEL MEASURED BY WELL DRILLER UPON COMPLETION OF WELL

- - APPROXIMATE BOUNDARY OF HYDROGEOLOGIC LAYER

Figure 3. Preliminary hydrogeologic section at Lac Vieux Desert. (Line of section shown in figure 1.) 
aquifer is likely to be under semi-confined or confined conditions and, therefore, may be less vulnerable to contamination from the surface than the shallower water-table aquifer.

\section{Ground-Water Levels}

Ground-water levels in the Lac Vieux Desert watershed, Vilas County, range from about 1,683 to $1,705 \mathrm{ft}$ above sea level and decrease toward Lac Vieux Desert (Patterson, 1989 , plate 1). The only available groundwater-level data for the Lac Vieux Desert watershed is that reported by water-well drillers (table 1). These measurements may not accurately reflect the actual depth to ground water. Each measurement was made in a newly constructed well, and the water level in the well may not have had sufficient time to equilibrate with the water level in the surrounding aquifer.

Depth-to-water ranges from above land surface at well L5 (flowing at time of installation) to $120 \mathrm{ft}$ below land surface at well L9. Well L9 is not typical because it is located southeast of Lac Vieux Desert where land surface elevation can be nearly $200 \mathrm{ft}$ higher than lake level and drumlins dominate the topography; most other wells drilled in the watershed are near the lake. Depth-to-water at well L25 at the Lac Vieux Desert Indian Community is 26 $\mathrm{ft}$ below land surface, and water levels in neighboring wells L26 and L27 are 18 and 35 $\mathrm{ft}$ below land surface, respectively. Wells L26 and L27 are in relatively low-lying areas. Water levels measured in wells on both sides of the state border, and the fact that ground-water flow generally is toward topographically low lying areas indicates that ground water in the watershed generally flows toward and discharges into the lake or into creeks that discharge into the lake. In the vicinity of the lake's outlet, however, a small ground-water outflow from the lake occurs.

\section{Water Quality}

Samples were collected from two domestic wells at the Lac Vieux Desert Indian Community on March 19 and 21, 1996 (wells L28 and
L29) and from a well at the Pow Wow Center (well L30) on October 10, 1996. These three wells are believed to be similar to wells completed in the shallow aquifer near Indian trust land. In order to avoid contamination of water samples, the sampling was conducted using ultraclean procedures, and quality-control samples described by Koterba and others (1995). The samples were analyzed for common ions, nutrients, and some trace metals. The physical and chemical characteristics of the samples are similar to those reported by Patterson (1989). Water from wells L28, L29, and L30 is moderately alkaline and has low concentrations of iron; however, the water is moderately hard. Calcium and bicarbonate are the major dissolved constituents in the ground water. Concentrations of nitrite and nitrate, total mercury, and total lead are below the USEPA's primary Maximum Contaminant Level (MCL) for these dissolved constituents.

Concentrations of sulfate, chloride, iron, and manganese in ground water are below the secondary MCL action levels. The concentration of copper in water from well L29 (210 micrograms per liter (ug/L)) is considerably higher than concentrations in water from nearby well L28 ( $<10 \mathrm{ug} / \mathrm{L})$ but still considerably less than the USEPA's secondary MCL of $1,300 \mathrm{ug} / \mathrm{L}$. Because the water sample for well L29 was collected from a tap at a residence the source of copper may be the dwelling's plumbing.

\section{SURFACE WATER}

\section{Water Levels in Lake Vieux Desert}

During 1913-28, lake-level measurements were made approximately weekly, and since 1929 , lake levels have been recorded daily by WVIC (Sam Morgan, Wisconsin Valley Improvement Company, 1995) (fig. 4). In addition, lake levels were monitored by the U.S. Geological Survey during 1973-91.

During the period of record, the average lake level was $1,680.5 \mathrm{ft}$ above sea level. The minimum and maximum observed lake level is $1,679.28$ and $1,682.16 \mathrm{ft}$ above sea level on September 19, 1925 and May 5-6, 1951, 
Table 2. Physical and chemical characteristics of water from wells near Lac Vieux Desert and water-quality standards for human consumption

[Concentrations are in milligrams per liter unless otherwise noted; drinking-water standards are U.S. Environmental Protection Agency (USEPA) Primary or Secondary Standards; analyses by U.S. Geological Survey except for tritium in water of wells 28 and 29 which were by University of Waterloo Environmental Isotope Laboratory; --, not analyzed; <, actual value is less than value shown]

Physical characteristic or water-quality constituent

USEPA

drinking

water Well Well Well Equip-

$\begin{array}{lllll}\text { stand- } & 28 & 29 & 30 & \text { ment }\end{array}$

ard blank

Date of sample

Well depth (feet below land surface)

Specific conductance, field

(microsiemens per centimeter at 25 degrees Celsius)

$\mathrm{pH}$, field (standard units)

Hardness, total (as $\mathrm{CaCO}_{3}$ )

Calcium, dissolved

Magnesium, dissolved

Sodium, dissolved

Potassium, dissolved

Bicarbonate $\left(\right.$ as $\left.\mathrm{HCO}_{3}\right)$

Sulfate, dissolved

Chloride, dissolved

Alkalinity, field (as $\mathrm{CaCO}_{3}$ )

Nitrogen, dissolved (as N)

Nitrogen, nitrite, dissolved (as N)

Nitrogen, nitrate, dissolved (as N)

Phosphorus, total

Arsenic, total (micrograms per liter)

Copper, total (micrograms per liter)

Iron, dissolved (micrograms per liter)

Lead, total (micrograms per liter)

Manganese, total (micrograms per liter)

Manganese, dissolved (micrograms per liter)

Mercury, total (micrograms per liter)

Tritium, total (tritium units)

$\begin{array}{ccccc}-- & 3 / 19 / 96 & 3 / 21 / 96 & 10 / 10 / 96 & - \\ -- & 84 & 42 & - & - \\ -- & 144 & 137 & 149 & -\end{array}$

$\begin{array}{lllll}6.5-8.5 & 7.7 & 8.1 & 8.1 & --\end{array}$

$\begin{array}{lllll}- & 71 & 64 & 72 & -\end{array}$

$\begin{array}{lllll}-- & 20 & 18 & 20\end{array}$

$\begin{array}{lllll}- & 5.2 & 4.7 & 5.3\end{array}$

$\begin{array}{lllll}-- & 2.1 & 2.1 & 2.4\end{array}$

$\begin{array}{llllll}- & - & - & - & 0.8 & -\end{array}$

$\begin{array}{llllll}- & 81 & 73 & - & -\end{array}$

$\begin{array}{lllll}250^{\mathrm{a}} & 6.4 & 6.6 & 8.1 & -\end{array}$

$\begin{array}{lllll}250^{\mathrm{a}} & 0.3 & 0.7 & 0.5 & -\end{array}$

$\begin{array}{llllll}-- & 66 & 60 & - & -\end{array}$

$\begin{array}{lllll}- & 2.0 & 0.2 & 0.5\end{array}$

$1^{\mathrm{b}} \quad<0.01 \quad<0.01 \quad 0.03 \quad-$

$\begin{array}{lllll}10^{\mathrm{b}} & 0.29 & 0.23 & - & -\end{array}$

$\begin{array}{lllll}-- & 0.06 & 0.03 & 0.02 & -\end{array}$

$\begin{array}{lllll}50^{\mathrm{b}} & 1 & 3 & -- & <1\end{array}$

$1,300^{\mathrm{a}} \quad<10 \quad 210 \quad--<10$

$\begin{array}{lllll}300^{\mathrm{a}} & 14 & 24 & 9 & -\end{array}$

$15^{\mathrm{b}} \quad<1 \quad<1 \quad--\quad<1$

$--\quad<10<10 \quad--<10$

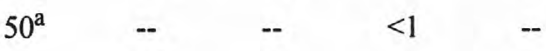

$2^{\mathrm{b}} \quad<0.1 \quad<0.1 \quad--\quad<0.1$

$\begin{array}{lllll}-- & 19.7 & 20.2 & 22.5 & -\end{array}$

\footnotetext{
${ }^{a}$ USEPA Secondary Maximum Contaminant Level for drinking water

${ }^{\mathrm{b}}$ USEPA Maximum Contaminant Level for drinking water
} 
respectively. On three occasions, the annual average lake level (fig. 4) increased more than one foot over a one or two year period. During 1918-19 and 1925-26 the average lake level rose $1.2 \mathrm{ft}$; during 1949-51 it rose nearly $1.5 \mathrm{ft}$. After each of these rising water events, water levels receded considerably slower than the rate at which water levels rose.

Between 1913 and 1950, the annual minimum lake level was greater than $1,680.00 \mathrm{ft}$ above sea level 6 times; since 1950, the annual minimum levels were slightly lower, ranging from $1,679.37$ to $1,679.80 \mathrm{ft}$ above sea level (fig. 4). Between 1913-50, the average lake level was about $1,680.7 \mathrm{ft}$; from 1950 to 1995 , the average lake level was about $1,680.3 \mathrm{ft}$ above sea level. Similarly, the maximum lake levels from 1913 to 1950 averaged about $1,681.5 \mathrm{ft}$; from 1950-1995, they averaged about $1,681.3 \mathrm{ft}$.

Although the lake level of Lac Vieux Desert is regulated, the annual lake-level fluctuations reflect changes in annual precipitation amounts. For example, lake-level declines occurred for the drought periods of 1918 , $1925,1932,1948,1958,1963,1976$, and 1988-89. Precipitation was below average during these periods. In 1963 and 1976, precipitation was 8 and 14 inches below average, respectively. High lake levels occurred in 1919-22, 1926-28, 1938-39, 1951-53, 1960, and 1983 (fig. 4). The correlation between high annual maximum lake levels and above average amounts of precipitation is more consistent after 1950 than from 1913-50.

\section{Water Quality}

During March 1996, water samples were collected at sites 3, 4, and 5 on ice covered Lac Vieux Desert (fig. 2). Water samples were collected $2 \mathrm{ft}$ below the base of the lake ice. These water samples were analyzed for nutrients, $\mathrm{pH}$, and specific conductance (table 3). Attempts were made to collect samples at sites 1 and 2 in Rice Bay; however, at both locations the lake ice was greater than $3 \mathrm{ft}$ thick and nearly in contact with the lake bottom. Site 5 is located near the deepest area of the lake where WVIC previously monitored water quality.
At sites 1, 2, and 3, a strong organic odor was detected, indicating reduced oxygen conditions under the ice. During October 1996, additional samples were collected at 10 sites on Lac Vieux Desert (table 4). Reducing conditions were not evident during the fall sampling period when dissolved oxygen concentrations ranged from 6.4 to $9.4 \mathrm{mg} / \mathrm{L}$ (milligrams per liter). Profiles of temperature, $\mathrm{pH}$, dissolved oxygen, and specific conductance are illustrated in table 5 for 5 of the 10 sites. Water depths at the remaining 5 sites were too shallow to collect profiles. Specific conductance and temperature data from these profiles also indicate that water in the lake is well mixed in the fall.

WVIC monitored water temperature and dissolved oxygen in the inflow and outflow at the Lac Vieux Desert dam and at site 5 (fig. 2) on a bimonthly basis during the 1970 to 1989 . Temperature of the inflow at the dam ranged from 0.2 degrees Celsius $\left({ }^{\circ} \mathrm{C}\right)$ on December 13,1983 to $25.2{ }^{\circ} \mathrm{C}$ on June 24,1987 , and dissolved oxygen ranged from $3.1 \mathrm{mg} / \mathrm{L}$ on March 29, 1988 to $14.0 \mathrm{mg} / \mathrm{L}$ on December 20, 1988. Temperature of the outflow at the dam ranged from $0.3^{\circ} \mathrm{C}$ on November 11,1983 to $25.7^{\circ} \mathrm{C}$ on July 22,1988 and dissolved oxygen ranged from $3.6 \mathrm{mg} / \mathrm{L}$ on April 14, 1982 to $14.4 \mathrm{mg} / \mathrm{L}$ on December 20, 1988. At site 5, dissolved oxygen at a $6.6 \mathrm{ft}$ sampling depth ranged from $1.8 \mathrm{mg} / \mathrm{L}$ on March 5, 1980 and February 13, 1981 to $11.5 \mathrm{mg} / \mathrm{L}$ on April 29, 1980 and May 17,1983 . Water temperature at this site and depth ranged from $3.8^{\circ} \mathrm{C}$ on March 5, 1980 to $23.7^{\circ} \mathrm{C}$ on July 28,1982 and July $27,1983$.

WVIC also analyzed for nitrate plus nitrite concentrations and $\mathrm{pH}$ in water from site 5 . Sampling depth ranged from about 3.1 to 38.4 $\mathrm{ft}$ below lake surface. Concentrations of nitrite plus nitrate ranged from 0.03 to $0.18 \mathrm{mg} / \mathrm{L}$. The average summer and fall $\mathrm{pH}$ were similar at 6.9 and 7.1 units.

Comparison of the water-quality data in tables 3 and 4 illustrate the differences between quality of water in the lake during fall and winter. Specific conductance during fall was about 67 microsiemens per centimeter $(\mu \mathrm{S} / \mathrm{cm})$; dur- 


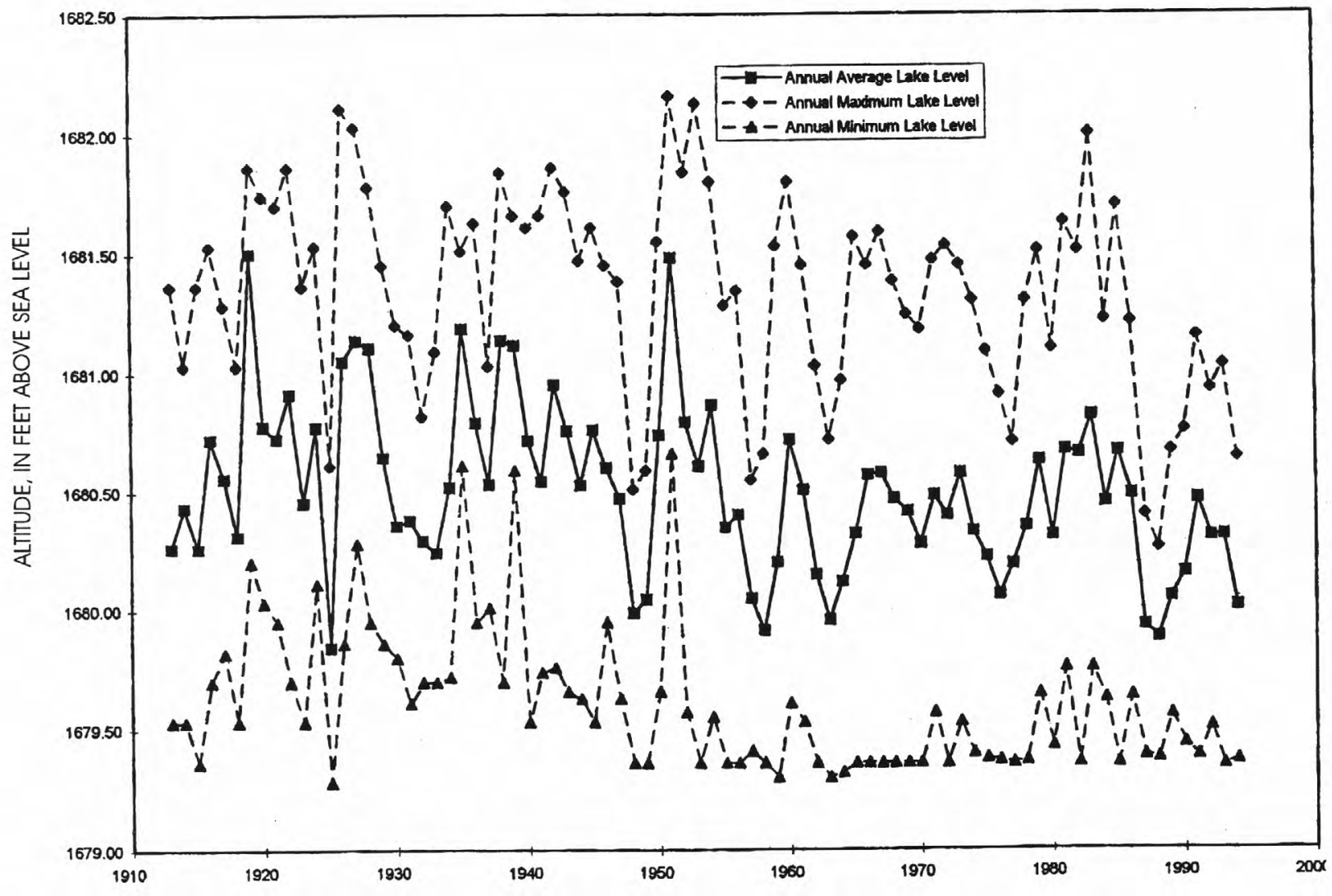

Figure 4. Water levels at Lac Vieux Desert, 1913-95. 
Table 3. Physical and chemical characteristics of water from three sites on Lac Vieux Desert, March 1996

[Concentrations are in milligrams per liter unless otherwise noted; analyses by U.S. Geological Survey;

$<$, actual value is less than value shown; samples collected on March 20-21, 1996.]

Physical characteristic or water-quality constituent

Site $3 \quad$ Site $4 \quad$ Site 5

Specific conductance, field

(microsiemens per centimeter at 25 degrees Celsius)

122

109

103

$\mathrm{pH}$, field (standard units)

7.0

7.0

7.1

Alkalinity (as $\mathrm{CaCO}_{3}$ )

55

49

46

Nitrogen, dissolved (as N)

0.9

0.6

0.7

Nitrogen, nitrite, dissolved (as $\mathrm{N}$ )

.01

$<.01$

$<.01$

Nitrogen, nitrate, dissolved (as N)

.07

.23

.34

Phosphorus, total (as P)

.17

.02

.03 
Table 4. Physical and chemical characteristics of water from ten sites on Lac Vieux Desert, October 1996

[Concentrations are in milligrams per liter unless otherwise noted; analyses by U.S. Geological Survey; --, not analyzed; <, actual value is less than value shown; samples collected on October 8-9, 1996.]

Physical characteristic or water-quality constituent

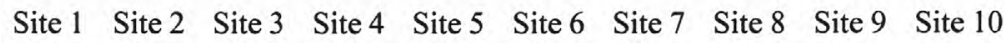

\begin{tabular}{|c|c|c|c|c|c|c|c|c|c|c|}
\hline $\begin{array}{l}\text { Specific conductance, field } \\
\text { (microsiemens per centimeter } \\
\text { at } 25 \text { degrees Celsius) }\end{array}$ & 67 & 67 & 67 & 67 & 66 & 67 & 67 & 68 & 67 & 67 \\
\hline $\mathrm{pH}$, field (standard units) & 7.6 & 7.6 & 7.4 & 7.2 & 7.4 & 7.6 & 8.7 & 7.5 & 7.6 & 7.3 \\
\hline Alkalinity (as $\mathrm{CaCO}_{3}$ ) & 33 & 34 & 33 & 33 & 33 & 33 & 34 & 33 & 34 & 33 \\
\hline Nitrogen, dissolved (as N) & 0.5 & $<0.1$ & 0.2 & 0.2 & 0.4 & $<0.1$ & 0.4 & 0.2 & $<0.1$ & 0.2 \\
\hline Nitrogen, nitrite, dissolved (as N) & .03 & .03 & .02 & .03 & .04 & .02 & .02 & .02 & .03 & .02 \\
\hline Phosphorus, total (as P) & $<.01$ & .01 & $<.01$ & $<.01$ & $<.01$ & $<.01$ & $<.01$ & .01 & $<.01$ & $<.01$ \\
\hline Phosphorus, dissolved (as P) & $<.01$ & $<.01$ & $<.01$ & .02 & $<.01$ & $<.01$ & $<.01$ & $<.01$ & $<.01$ & $<.01$ \\
\hline Phosphorus, ortho, dissolved (as P) & $<.01$ & $<.01$ & $<.01$ & $<.01$ & $<.01$ & $<.01$ & $<.01$ & $<.01$ & -- & $<.01$ \\
\hline
\end{tabular}


Table 5. Physical characteristics of water in Lac Vieux Desert at five sites profiled October 1996

[mg/L, milligrams per liter; $\mu \mathrm{S} / \mathrm{cm}$, microsiemens per centimeter at 25 degrees Celsius]

\begin{tabular}{lllll}
$\begin{array}{l}\text { Depth below } \\
\text { lake surface, } \\
(\text { feet })\end{array}$ & $\begin{array}{l}\mathrm{pH}, \\
\text { field, } \\
\text { (units) }\end{array}$ & $\begin{array}{l}\text { Oxygen } \\
\text { dissolved, } \\
(\mathrm{mg} / \mathrm{L})\end{array}$ & $\begin{array}{c}\text { Specific } \\
\text { conductance, } \\
(\mu \mathrm{S} / \mathrm{cm})\end{array}$ & $\begin{array}{c}\text { Temperature, } \\
\text { (degrees } \\
\text { Celsius })\end{array}$ \\
\hline
\end{tabular}

Site 3

\begin{tabular}{lllll}
\hline & & & & \\
2 & 7.4 & 9.4 & 67 & 10.1 \\
4 & 7.3 & 9.4 & 67 & 10.0 \\
6 & 7.3 & 9.3 & 67 & 9.8 \\
8 & 7.3 & 9.1 & 67 & 9.6 \\
10 & 7.3 & 9.3 & 67 & 9.5 \\
11 & 7.3 & 9.3 & 67 & 9.5 \\
\hline
\end{tabular}

Site 4

\begin{tabular}{lllll}
\hline & & & & \\
2 & 7.2 & 8.6 & 67 & 10.0 \\
4 & 7.2 & 8.5 & 67 & 9.7 \\
6 & 7.2 & 8.5 & 67 & 9.7 \\
8 & 7.3 & 8.5 & 67 & 9.7 \\
10 & 7.2 & 8.5 & 67 & 9.7 \\
\hline
\end{tabular}

Site 5

\begin{tabular}{|c|c|c|c|c|}
\hline 2 & 7.4 & 8.7 & 66 & 10.0 \\
\hline 4 & 7.4 & 8.7 & 66 & 9.8 \\
\hline 6 & 7.4 & 8.7 & 66 & 9.8 \\
\hline 8 & 7.4 & 8.7 & 66 & 9.7 \\
\hline 10 & 7.4 & 8.7 & 66 & 9.7 \\
\hline 12 & 7.4 & 8.7 & 66 & 9.7 \\
\hline 14 & 7.4 & 8.7 & 66 & 9.6 \\
\hline 16 & 7.4 & 8.7 & 66 & 9.6 \\
\hline 18 & 7.4 & 8.6 & 66 & 9.6 \\
\hline 20 & 7.4 & 8.6 & 66 & 9.6 \\
\hline 22 & 7.4 & 8.5 & 66 & 9.6 \\
\hline 24 & 7.4 & 8.4 & 66 & 9.6 \\
\hline 26 & 7.3 & 7.9 & 66 & 9.6 \\
\hline 28 & 7.2 & 6.4 & 66 & 9.6 \\
\hline \multicolumn{5}{|c|}{ Site 9} \\
\hline 2 & 7.5 & 8.5 & 68 & 9.6 \\
\hline 4 & 7.5 & 8.5 & 68 & 9.6 \\
\hline 6 & 7.6 & 8.4 & 67 & 9.6 \\
\hline \multicolumn{5}{|c|}{ Site 10} \\
\hline 2 & 7.3 & 8.8 & 67 & 9.7 \\
\hline 4 & 7.3 & 9.0 & 67 & 9.7 \\
\hline 6 & 7.3 & 8.7 & 67 & 9.7 \\
\hline 8 & 7.3 & 8.7 & 67 & 9.6 \\
\hline 10 & 7.3 & 8.7 & 67 & 9.6 \\
\hline 12 & 7.3 & 8.4 & 67 & 9.6 \\
\hline
\end{tabular}


ing winter it ranged from 103 to $122 \mu \mathrm{S} / \mathrm{cm}$. Likewise, alkalinity, nitrogen, and phosphorus were all less in samples collected in fall than those collected in the winter. However, greater concentrations of nitrite were detected in samples collected in fall compared to the winter samples.

\section{SUMMARY}

All ground-water supplies in the Lac Vieux Desert watershed are obtained from wells drilled in Pleistocene glacial deposits. Analysis of well data indicates that a gravel layer near the bedrock surface is a highly productive aquifer.

None of the constituents measured in samples collected from three wells at the Lac Vieux Desert Indian Community exceed Maximum Contaminant Levels. Calcium and bicarbonate are the major dissolved constituents in the ground water.

During March 1996, surface-water samples were collected at three sites on ice covered Lac Vieux Desert. During October 1996, samples were collected at 10 sites on the lake. Profiles of $\mathrm{pH}$, dissolved oxygen, specific conductance, and temperature indicate that the lake is well mixed in the fall but not in winter when the lake was ice covered.

During 1913-95, the minimum and maximum daily recorded lake level was $1,679.28$ and $1,682.16 \mathrm{ft}$ above sea level on May 17 and 18, 1925 and September 24, 1951, respectively. Since the early 1950's, the annual minimum lake-level was lower and less variable. During the period of record, the average lake level is $1,680.5 \mathrm{ft}$ above sea level. There have been three events where the annual average lake level has increased more than one foot over a one or two year period. During 1918-19 and 1925-26 the average lake level rose $1.2 \mathrm{ft}$ and during 1949-51 water levels rose nearly $1.5 \mathrm{ft}$. Water levels receded slower than they rose after all 3 of these events.

Although the lake level of Lac Vieux Desert is regulated, historical levels show yearto-year fluctuations that reflect transient changes in precipitation amounts. These historical water-level trends are similar to trends in annual precipitation amounts, however, they correlate better after 1950 than before.

\section{REFERENCES CITED}

Attig, John W., 1985, Pleistocene Geology of Vilas County, Wisconsin: Wisconsin Geological and Natural History Survey Information Circular 50, $32 \mathrm{p}$.

Doonan, C.J., and Hendrickson, G.E., 1968, Ground water in Gogebic County, Michigan: Michigan Geological Survey Water Investigation 8, $22 \mathrm{p}$.

Koterba, K.T., Wilde, F.D, and Lapham, W.W., Ground-water data collection protocols and procedures for the national water-quality assessment program; collection and documentation of water-quality samples and related data: U.S. Geological Survey OpenFile Report 95-399, 113 p.

Morey, G.B., Sims, P.K., Cannon, W.F., Mudrey, M.G., Jr., and Southwick, D.L., 1982, Geologic map of the Lake Superior Region: Minnesota, Wisconsin, and northern Michigan (bedrock), Minnesota Geological Survey.

Patterson G.L., 1989, Water Resources of Vilas County, Wisconsin: University of WisconsinExtension Geological and Natural History Survey, Miscellaneous Paper 89-1, 46 p.

U.S. Environmental Protection Agency, 1991, Wellhead protection strategies for confined-aquifer settings, Washington, D. C., Office of Ground Water Protection, variously paginated.

Wisconsin Valley Improvement Company, 1990, WVIC water quality monitoring data, volume I Natural-lake reservoirs: Wisconsin Valley Improvement Company, Wausau, Wisconsin, variously paginated. 
